\title{
'A Study on Growth and Development of Open Source Software in Education'
}

\author{
Dr. Manjari Agarwal \\ Assistant Professor School of Management Studies and Commerce Uttarakhand \\ Open University, Haldwani State: Uttarakhand
}

\begin{abstract}
Open source software is a novice concept which has brought heralds of success in IT Industry. These have modeled a paradigm shift in technological developments by bringing new metaphors of cooperation and collaboration. The future of Open Source Software in education is filled with endless possibilities. In this background, the basic premise of the paper is to explore the growth and development of Open Source Software especially in the field of education. The paper identifies the importance of Open Source Software and its rationale in the educational institutions. It goes on to look the key differences between the two terms used in open source community. Further, it also concludes with the list of common OSS used in academics.
\end{abstract}

Key Words: Open Source Software; Technology; Education

"The most unfortunate thing is that India still seems to believe in proprietary solutions. Further spread of IT which is influencing the daily life of individuals would have a devastating effect on the lives of society due to any small shift in the business practice involving these proprietary solutions. It is precisely for these reasons open source software need to be built which would be cost effective for the entire society. In India, open source code software will have to come and stay in a big way for the benefit of our billion people. " - A.P.J. Abdul Kalam $^{l}$

\section{Introduction}

Today, Information and Communication Technology has provided us an ability of flexibility and access to information and resources. It has not only empowered the IT community to take part in exploring new narratives but has also created a platform where intellectual work could be created and shared from anywhere to anyone at anytime. Open source software is a novice concept which has brought heralds of success in IT Industry. These have modeled a paradigm shift in technological developments by bringing new metaphors of cooperation and collaboration.

\section{Open Source Software- A Notion to Approach}

Open Source Softwares are the one in which source code is made available to the users who have the right to access, use, contribute modify, change, improve and distribute under non-restrictive licensing terms. Thus, the programming instructions of the software are delivered to anyone using the software so that these can be customized as per one's own requirement. Further, anyone can contribute in improving the source code, and thereby, finding the loopholes and reporting it back to developer or developers. Moreover, modified source code can be redistributed under interoperable or non-existent license terms and agreements. Open Source Software has been defined by Jim Whitehurst, President and CEO of RedHat (2009) "as a collaborative softwaredevelopment method that harnesses the power of peer review and transparency of process to develop code that is freely accessible." ${ }^{2}$

As explained by Neil Gandal (2011) "Open source software methods rely on developers who reveal the source code under an open source licence. Under certain types of open source licences, any further development using the source code must also be publicly disclosed." ${ }^{3}$

Friedman Thomas (2006) explains the concept in memorable way as "Think of these communities as chat rooms with freelance engineers who collaborate together to produce a piece of software, with everyone contributing improvements to the source code to make it sing and dance better, and using it, as long as they conform to the license rules of that particular source community". ${ }^{4}$

Therefore, these are developed either by funding agencies or by group of software developers working under some common kinship for onwards distribution to much larger community. Because of the main feature of cost effectiveness, these softwares have mitigated the need and importance of proprietary softwares. Hence, use of Open Source Software (will be termed as OSS for the rest of the paper) neither charge any license fees for its usage nor does it place restrictions on the use of other softwares which are installed along with the licensed software.

The main features of OSS as extracted from the definition provided by open source initiatives are presented for broader understanding of the concept: 
1. The source code in its intact form is given to the users and they have right to modify it.

2. Users are also allowed to redistribute or even sell the software to one or more parties without paying any fees or royalty for such sale.

3. Modifications, improvements or even alterations are allowed in the source code and can be distributed under the same license terms of the original software. Derived works from the original software are also allowed. Hence, any bugs or errors can be traced and reported to the creator and the community for improvements in the quality, applicability and functionality.

4. The license shall not discriminate any person or group of persons.

5. No specific technology or computer interface shall be promoted by the license provided for using OSS.

6. Source-code can be restricted only if patch files are given with the source code for the purpose of modifying the program at builds time. In such case, license permit for producing derived works with a different name or with different version.

\section{Free Software Vs Open Source Software}

There are two set of philosophies or ideologies regarding this software movement, one school of thought proclaims it as software freedom and call it as free software (term promoted by Richard Stallman) and the other call it as Open Source Software (term connoted in a strategy session held at Palo Alto, California in 1998), is also coined as 'Intellectual Commons Community' by Thomas Fried man ${ }^{4}$. The main promoters of this terminology are Eric S.Raymond, Bruce Perens, Larry Wall, Guido van Rossum and Paul Vixie. In Free Software the user has a freedom to copy and reuse the software but it is not cost free. The derived work or innovations are required to be contributed back to the community. Richard Stallman explained free software as one which has freedom to run the program as for one's purpose, freedom to modify the programme as per one's needs, freedom to redistribute copies either for gratis or for some fee and freedom to redistribute modified versions of the program, so that the community can be benefitted from some improvements. ${ }^{5}$

However, both serve as a replacement or substitute to the proprietary softwares but still the main differences as inferred from the various viewpoints are categorized as under

\begin{tabular}{|c|c|c|}
\hline S. No & Free Software & Open Source Software \\
\hline 1. & It is termed as a social movement. & $\begin{array}{l}\text { It is termed as concept or a methodology of developing softwares } \\
\text { by some IT professionals. }\end{array}$ \\
\hline 2. & It is licensed with GNU General Public License. & $\begin{array}{l}\text { It is either licensed with GPL or some other license authority for } \\
\text { the integration of software other than free one. }\end{array}$ \\
\hline 3. & $\begin{array}{l}\text { The right is given to use and modify under the } \\
\text { same license terms and hence is not for the review } \\
\text { process. }\end{array}$ & $\begin{array}{l}\text { It is a peer review in which anyone can contribute for the } \\
\text { improvement of the software. }\end{array}$ \\
\hline 5. & $\begin{array}{l}\text { Freedom is in terms of software price since the } \\
\text { license doesn't give the rights to reuse or } \\
\text { repackage the source code. }\end{array}$ & $\begin{array}{l}\text { In open source software, freedom pertains to the licensing } \\
\text { schemes is much more than the price. Here cost of reuse is zero. }\end{array}$ \\
\hline 6. & $\begin{array}{l}\text { Sometimes code is kept private therefore } \\
\text { competitors have to reinvent their versions right } \\
\text { from scratch. }\end{array}$ & $\begin{array}{l}\text { Derived works termed as forking can be taken from original } \\
\text { source code which can be used for modifying or adding new } \\
\text { features, interfaces etc. }\end{array}$ \\
\hline
\end{tabular}

These two approaches sprouted a new terminology named FOSS, Free and Open Source Software or Free Libre Open Source Software in which these concepts have been relatively blended.

\section{Advantages of Open Source Software over Proprietary Software in Education}

The advantages of using open source learning software's are as follows:

- Schools, Universities and other educational institutions are been financially burdened for paying heavily to software companies for using their products. Open Source softwares are freely available and they are sometimes better alternative to proprietary softwares. Further, users are not required to pay license fees annually for using these softwares.

- Open source software can be easily customised as per the requirements of educational institutions. New features and tools can be imported freely to learning management systems and enterprise resource planning systems.

- Documentation and help for installing and using the OSS is available on the respective OSS website. Therefore, it will save time and cost of purchasing manuals and books for operating them. Further, developers of the softwares also respond to the questions and queries regularly for rendering continuous help to the users.

- Many of OSS are multilingual like Moodle, Claroline, Discussion Forums and the likes, so these can be easily localised to the meet the educational goals. 
- Meticulous and continuous improvements are made in these softwares by OSS community in form of new versions. Since, the source code is easily available; hence it is subject to modifications from all over the world.

- Adaptation of open softwares will help students in learning how technology works and can will foster and amplify creativity in them especially at the secondary level and OSS community also helps them to publish their work.

\section{Importance of Open Source Software in Education}

There has been consistent growth in the use of open source software in the field of education all over the world. OSS has attempted to transform the education system from traditional to more vibrant and more creative cognitive domain. It has not only assisted in developing the Universities or educational institutions virtually but has also complemented the traditional teaching in attaining new heights. Due to advent of Open Source Softwares, teachers, evaluators, curriculum developers, evaluators, academic managers and trainers are being compelled to rethink the ways of harnessing technology in their academic endeavors. The growth of OSS in the recent years has ameliorated the delivery of high quality content with increased access to information and communication technology at substantially lower cost. It has therefore significantly contributed in bridging digital divide across the world. Adapting OSS in educational system will not only help in curtailing explicit and implicit cost of purchasing proprietary softwares but will also discourage piracy by the people who are unable to afford the purchase of licensed copies of proprietary softwares. It has also given an opportunity to the knowledge seekers who are unable to attend on-campus education or who have limited access to educational resources and those who wish to study for the sake of knowledge and learning. OSS has also fostered creativity, flexibility, adaptability, reliability and quality in open and free dissemination of knowledge and information by educational institutions. In coming years, effective construction of voluntary communities of interest using Open Source Software will dominate individual vision and knowledge. (Eric Raymond, 2000) ${ }^{6}$ Further in a study conducted by Kotwani Gunjan and Kalyani Pawan, revealed that the students who learned the mathematics concepts from open source software grasped the concepts in less time period and in conformance with the syllabus of the class.

Attwell Graham (2005) also assessed that OSS has contributed in social reward and recognitions in respect to sharing and collaborative development of learning applications. Further, at the same time the emphasis of lifelong learning is a key force in creating awareness regarding the different types of knowledge and of developing software to support wider forms and contexts of learning. ${ }^{8}$ There is one more point of view in regard to OSS because these emphasise on peer review, open source provides a particularly good vehicle for education (Lakhani and Wolf, 2005). ${ }^{9}$

Thus in the wake of the above, it is assessed that OSS has marked its relevance for schools, colleges, distance learning, healthcare, professional and vocational educational institutions. The growth and development of OSS in Education is being studied from the following dimensions:

\section{Contribution of OSS in Academic Process-}

Use of open source software has provided a great opportunity for educational institutions in improving teaching and learning process. Teachers can now use their subject expertise to select appropriate OSS which will help them in meeting specific learning objectives. Virtual universities like University of Phoneix are offering professional programmes in an online mode successfully. Education portals like Edusoft, Edumate provides customized community software which features easy ways for students to connect with their professors and their peers to get them more engaged in their classes.

Open Courseware like of MIT, Yale and likes has provided free and open digital publication of high quality study materials of renowned Institutions and Universities. These has really complemented OSS movement as they are free and openly licensed which is accessible to anyone at anytime.

Being connected with the web is the need of the hour for the educational institutions. OSS like Mozilla Firefox, Galeon, Konqueror has secured user authentication and has authorised users to access the web and has made the browsing easier for teacher, researchers and students.

Another important development in OSS movement is the upsurge of Open Source Learning Management System like Moodle, Sakai, Blackboard etc. which are the electronic platforms used to launch and manage e-learning programmes which ensures registration, course administration, problem solving, interaction, tracking and reporting. Advent of LMS has given breakthrough to education by replacing the conventional classroom based teaching to interactive and collaborative learning. Online marking tools enable instructors in giving feedback to the learners and helps in evaluating assignments, answer scripts online. Course development tools are used for developing effective and interactive course materials by incorporating text, audio, video, graphics, and animation and multimedia tools. University of Colorado was the first university which used a web based system to offer online programme. 
Streaming and Podcasting Open Source Softwares like Matterhorn, Miro video converter, VLC Media Player, ipod disk and likes helped in managing audio and video contents. Lectures recording can be produced; existing video lectures can be managed and can be served to designated distribution channels. It also provides user interfaces in which students can effectively learn from videos. Further, graphical applications like inkjet are the power tools use to create graphics. Similarly, Open Graphics Library is a cross language multiplatform API for developing $2 \mathrm{D}$ and $3 \mathrm{D}$ computer graphics. It is generally used in CAD, virtual reality, scientific visualisation, flight simulations and video games.

( A list depicting commonly used softwares and their application in education has been compiled for gaining greater insight of its relevance )

\section{Contribution of OSS in Administrative Functions of Educational Institutions-Infrastructure Convergence}

OSS has also supported administrative functions especially in customizing Student Information Systems as per the institutional requirement as against proprietary software. One such example is the use of open office in many universities and schools instead of Microsoft office for operating system. Maintaining and linking Open Source Software of Student Information System like Projectfedena with LMS has also made functioning transparent. Management of student's records, records of revenues and expenses, academic records, registration of students has made administration of educational institutions more efficient by using initiatives like SchoolTool. Web servers like Apache can also be used to host public and internet sites. Further MYSQL is used as database server which is also adopted by Institutions for infrastructural support. Open Source LMS is used for site management, user management and course management.

\section{OSS from learner's perspective}

If used correctly and suitably, OSS can bestow blessings on students community as learning can be made more interesting, interactive, creative, and independent by applying new pedagogical methods and design which these softwares has complemented. Software like Interactive white board, Mathematica, Google scholar, Sakai, School Tool Open student and others has explored new vistas of learning like home-based learning, e learning, seminar based learning, virtual learning and collaborative learning.

\section{OSS towards building a Knowledge Society}

Synchronous and Asynchronous communications provided in LMS through Discussion Forums and real time chats, video conferencing, and community networking allows users to make social connections, study groups and independent collaborative teams. Instruction for students in the use of the software and better preparation for the challenges of collaborative learning, especially negotiation and other group skills, are likely to produce a more effective learning system. (Curtis and Lawon, 2001) ${ }^{9}$

Using open source blogging platforms like world press and Lifetype and open online portals helps in creating, sharing and assimilating knowledge across the worldwide thereby filling the developmental divide.

\section{Conclusion and Discussion}

After studying the entire journey of open source software, it is found that Open Source Softwares for the universities, schools, educational and training institutions have not only provided an opportunity but is also an important resource for the institution. Renowned Universities and Schools like MIT, Harvard, Phoenix and many other schools at Ontario, Canada, America, to name few and even some schools at Kerala (as promoted by State Government) are captivating the advantage of these community developed softwares. This movement has lanced the share of proprietary softwares to Linux and others because of low cost burden, freedom to use and swift association with the latest technology. Thus, the use of OSS has promoted freedom to think, use, implement, innovate, moderate and develop new software platforms which can take technological intervention in teaching-learning process to great heights. Therefore, the key question now is to ponder upon as to how to spread this revolution in educational institutions across the country.

\section{References:}

[1]. Quoted from a Speech in May,2003, http://tech.groups.yahoo.com/group/bytesforall_readers/message/2086 last assessed $19 / 06 / 2013$

[2]. Whitehurst Jim (2009), "Open Source: Narrowing the Divides between Education, Business, and Community", EDUCAUSE Review, vol. 44, no. 1 (January/February 2009), Page No. 70-71. http://www.educause.edu/ero/article/open-source-narrowingdivide-between-education-business-and-community, last accessed 16 June, 2013

[3]. Gandal Neil, on Vox posted on (September, 2011), "Open Source Software: Issues and Trends", http://www.voxeu.org/article/opensource-software-issues-and-trends, last accessed 16 June, 2013

[4]. Friedman Thomas (2006), "The World is Flat", Penguin Books, Chapter One Page No. 962006 Edition

[5]. Stallman Richard M. (2010) "Free Software, Free Society: Selected Essays of Richard M. Stallman”, Boston: GNU Press, Page no. 22 , 2nd ed. 
[6]. Raymond Eric(2000), "The Cathedral and the Bazaar", The Social Context of Open-Source Software", http://www.catb.org/esr/writings/homesteading/cathedral-bazaar/ar01s11.html

[7]. Kotwani Gunjan and Kalyani Pawan (2011), “Open Source Software (OSS): Realistic Implementation of OSS in School Education", http://ojs.uok.edu.in/ojs/index.php/crdr/article/view/173/156, Last accessed 19/06/2013

[8]. Graham Attwell (2005), "What is the Significance of Open Source Software for the education and training community?", http://oss2005.case.unibz.it/Papers/OES/EK4.pdf, Last accessed 19/06/2013.

[9]. Stephen M. Maurer and Scotchmer Suzanne, "Open Source Software: The New Intellectual Property Paradigm", http://www.nber.org/papers/w12148

[10]. Curtis David D. and Lawson Michael J., (2001), "Exploring Collaborative Online Learning”, JALN Volume 5, Issue 1 - February 2001 , http://wikieducator.org/images/6/60/ALN_Collaborative_Learning.pdf

\section{Bibliography}

Books

[11]. Anderson Terry (2008 (Editor), The Theory of Online Learning, AU Press, Athabasca University, 2nd ed.

[12]. Friedman Thomas (2006), The World is Flat, Penguin Books, Chapter One Page No. 962006 Edition

[13]. 2. Stallman Richard M. (2010) Free Software, Free Society: Selected Essays of Richard M. Stallman, Boston: GNU Press, Page no. 22,2 nd ed.

\section{Web links Referred}

[14]. Curtis David D. and Lawson Michael J., (2001), JALN Volume 5, Issue 1 - February 2001 , http://wikieducator.org/images/6/60/ALN_Collaborative_Learning.pdf, last accessed 15/06/2013

[15]. Graham Attwell (2005), "What is the significance of Open Source Software for the education and training community?", Proceedings of the First International Conference on Open Source Systems, Genova, 11th-15th July 2005, Marco Scotto and Giancarlo Succi (Eds.), pp. 353-358, last accessed 17/06/2013

[16]. Gandal Neil, on Vox posted on (September, 2011), "Open Source Software: Issues and Trends", http://www.voxeu.org/article/open-source-software-issues-and-trends, last accessed 16 June, 2013

[17]. Kotwani Gunjan and Kalyani Pawan (2011), "Open Source Software (OSS): Realistic Implementation of OSS in School Education”, http://ojs.uok.edu.in/ojs/index.php/crdr/article/view/173/156, Last accessed 19/06/2013

[18]. Lakhan Shaheen E and Jhunjhunwala Kavita (2008), “Open Source Software in Education”, Educause, Quarterly, Number2,

[19]. Neil Butcher(Organiser), Kanwar Asha and Uvalic'-Trumbic', (Editors) (2011), "A Basic Guide to Open Educational Resources (OER)", Common wealth of learning ablishers and http://www.col.org/resources/publications/Pages/detail.aspx?PID=357 last accessed 16/06/2013.

[20]. Stephen M. Maurer and Scotchmer Suzanne, "Open Source Software: The New Intellectual Property Paradigm", http://www.nber.org/papers/w12148, last accessed 14/06/2013

[21]. Sife A. S., Lwoga E.T. and Sanga C. (2007), "New technologies for teaching and learning: Challenges for higher learning institutions in developing countries", International Journal of Education and Development using Information and Communication Technology (IJEDICT), Vol. 3, Issue 2, pp. 57-67., http://ijedict.dec.uwi.edu/viewarticle.php?id=246/, last accessed 16/06/2013

[22]. Scacchi Walt (2004), Understanding Open Source Software Evolution, Walt October 2004 (Original version April 2003), http://www.ics.uci.edu/ wscacchi/Papers/New/Understanding-OSS-Evolution.pdf, last accessed 18/06/2013

[23]. Walt Scacchi, Joseph Feller (2006), Brian Fitzgerald, Scott Hissam and Karim Lakhani, "Understanding Free/Open Source Software Development Processes", http://citeseerx.ist.psu.edu/viewdoc/summary?doi=10.1.1.74.4302, last accessed 18/06/2013.

[24]. Whitehurst Jim (2009), "Open Source: Narrowing the Divides between Education, Business, and Community, EDUCAUSE Review”, vol. 44, no. 1 (January/February 2009), Page No. 70-71. http://www.educause.edu/ero/article/open-source-narrowingdivide-between-education-business-and-community, last accessed 14/06/2013

[25]. http://opensource.org/ The Open Source Definition _ Open Source Initiative/

[26]. Blog posting "Why Free software is better than Open Source", http://www.gnu.org/philosophy/free-software-for-freedom.html

[27]. Article posted by Revathi Krishnan, Difference between free software and open source software, http://suyati.com/differencebetween-free-software-and-open-source-software/

\section{Journals /Magazines}

1. Linux For You, The Complete Magazine on Open Source: Volume 10 Issue 07 September, 2012

Volume 10, Issue, 09, November, 2012

Volume 10, Issue 08, October, 2012

Volume 10, Issue 12, February, 2013

Volume-11, Issue 04, March 2013

Open Source For You, Volume 10, Issue-01, April,2013 
Appendix

Appendix: List of the Most Accessed Open Source Software in Education- A Bird's- Eye view

\begin{tabular}{|c|c|c|c|c|c|c|c|}
\hline S.No & $\begin{array}{l}\text { Catego } \\
\text { ry }\end{array}$ & $\begin{array}{l}\text { Open } \\
\text { Source } \\
\text { Software }\end{array}$ & $\begin{array}{l}\text { Alternative } \\
\text { to } \\
\text { proprietary } \\
\text { software }\end{array}$ & Features & Used by & Benefits of OSS in Education & $\begin{array}{l}\text { Links/ } \\
\text { Reference }\end{array}$ \\
\hline 1. & $\begin{array}{l}\text { LMS/ } \\
\text { CMS }\end{array}$ & Moodle & $\begin{array}{l}\text { Blackboard } \\
\text { Echo } 360 \\
\text { Desire2Learn } \\
\text { StudyWiz } \\
\text { Frog }\end{array}$ & $\begin{array}{l}\text { Acronym for Modular } \\
\text { Object-Oriented Dynamic } \\
\text { Learning Environment } \\
\text { Can be installed on any } \\
\text { computer that can run PHP } \\
\text { and SQL database. } \\
\text { It can also run on } \\
\text { Windows and Mac } \\
\text { operating systems and } \\
\text { Linux. } \\
\text { Moodle facilitate the } \\
\text { following: Assignment } \\
\text { submission, Discussion } \\
\text { forum } \\
\text { File downloading } \\
\text { available } \\
\text { Grading } \\
\text { Online calendar } \\
\text { Online news and } \\
\text { announcement (College } \\
\text { and course level) } \\
\text { Online quiz } \\
\text { Wiki } \\
\text { Reference- } \\
\text { https:/en.wikipedia.org wi } \\
\text { kiMoodle }\end{array}$ & $\begin{array}{l}\text { The Open } \\
\text { University, } \\
\text { UK } \\
\text { Wharton } \\
\text { County Junior } \\
\text { College } \\
\text { University of } \\
\text { Texas at San } \\
\text { Antonio } \\
\text { UNH } \\
\text { Cooperative } \\
\text { Extension- } \\
\text { eLearning } \\
\text { The Center for } \\
\text { Child and } \\
\text { Family Studies } \\
\text { Online } \\
\text { Training }\end{array}$ & $\begin{array}{l}\text { A centralized pool or integrated } \\
\text { software which is complete } \\
\text { package that automates } \\
\text { administration, tracking and } \\
\text { reporting of online programmers. } \\
\text { Academic and administrative } \\
\text { functions are included in the } \\
\text { framework. } \\
\text { It facilitate instructor in managing } \\
\text { course and communicating with } \\
\text { the learners. } \\
\text { Can be used for Online Learning } \\
\& \text { Blended with Big Blue Button } \\
\text { to create Virtual Class Room } \\
\text { Environment. }\end{array}$ & $\begin{array}{l}\text { http:/docs.moodl } \\
\text { e.org/25/en/About } \\
\text { Moodle } \\
\text { https:/en.wikiped } \\
\text { ia.org wikiMoodl } \\
\text { e } \\
\text { http:/xolotl.org bl } \\
\text { og xolotl who- } \\
\text { using-salkai- } \\
\text { moodlehttp:/xolo } \\
\text { tl.orgblog xolotl } \\
\text { who-using-sakai- } \\
\text { moodle }\end{array}$ \\
\hline 2. & & $\begin{array}{l}\text { Sakai CLE } \\
\text { Sakai OAE }\end{array}$ & $\begin{array}{l}\text { Blackboard } \\
\text { Echo } 360\end{array}$ & $\begin{array}{l}\text { Comprises of the } \\
\text { following: }\end{array}$ & $\begin{array}{l}\text { Abilene } \\
\text { Christian } \\
\text { University }\end{array}$ & $\begin{array}{l}\text { Research, portfolios and group } \\
\text { projects are possible using } \\
\text { collaborative tools. }\end{array}$ & $\begin{array}{l}\text { http:/wwww.sakaip } \\
\text { roject.org } \\
\text { http:/en.wikipedi }\end{array}$ \\
\hline & & & $\begin{array}{l}\text { Desire2Leam } \\
\text { StudyWiz } \\
\text { Frog }\end{array}$ & $\begin{array}{l}\text { My workplace tools } \\
\text { Generic collaborative } \\
\text { tools } \\
\text { Teaching tools } \\
\text { Portfolio tools etc. } \\
\text { My sakai widgets } \\
\text { Includes document } \\
\text { distribution } \\
\text { Gradebook } \\
\text { Livechat } \\
\text { Assignment uploads and } \\
\text { online testing }\end{array}$ & $\begin{array}{l}\text { - Northwest } \\
\text { University } \\
\text { - University } \\
\text { ofTexas M.D. } \\
\text { Anderson } \\
\text { Cancer Centre }\end{array}$ & $\begin{array}{l}\text { It also includes wiki, mailing list, } \\
\text { archives and RSS reader. }\end{array}$ & $\begin{array}{l}\text { a.org wiki Salkai } \\
\text { Project } \\
\text { http:/www.salcaip } \\
\text { roject.org organiz } \\
\text { ation-list }\end{array}$ \\
\hline 3. & & Canvas & $\begin{array}{l}\text { Blackboard } \\
\text { Echo } 360 \\
\text { Desire2Learn } \\
\text { StudyWiz } \\
\text { Frog }\end{array}$ & $\begin{array}{l}\text { Cloud-hosted learning } \\
\text { management system }\end{array}$ & $\begin{array}{l}\text { Auburn } \\
\text { University, } \\
\text { Brown } \\
\text { University, } \\
\text { New Mexico } \\
\text { State } \\
\text { University, } \\
\text { and the Utah } \\
\text { Education } \\
\text { Network } \\
\text { (including } \\
\text { University of } \\
\text { Utah and Utah } \\
\text { State } \\
\text { University). It } \\
\text { is currently } \\
\text { being rolled } \\
\text { outby the } \\
\text { University of } \\
\text { Maryland and } \\
\text { the University }\end{array}$ & $\begin{array}{l}\text { It is learning management system } \\
\text { which can aid in creating course } \\
\text { contents with the help of rich content } \\
\text { editor, speed up grading, and can } \\
\text { track learning outcomes and can send } \\
\text { notifications through email to the } \\
\text { learners and colleagues. }\end{array}$ & $\begin{array}{l}\text { http://www.turn } \\
\text { keylinux.org/scr } \\
\text { eenshots/canvas- } \\
\text { home }\end{array}$ \\
\hline
\end{tabular}




\begin{tabular}{|c|c|c|c|c|c|c|c|}
\hline & & & & & $\begin{array}{l}\text { of } \\
\text { Washington. } \\
\text { Refernce: } \\
\text { http://www.ut } \\
\text { exas.edu/its/c } \\
\text { anvas- } \\
\text { project/ }\end{array}$ & & \\
\hline 4. & & .LRN & \begin{tabular}{|l|} 
Blackboard \\
Echo 360 \\
Desire2Learn \\
StudyWiz \\
Frog
\end{tabular} & $\begin{array}{l}\text { Supportmultiple } \\
\text { languages, dialects and } \\
\text { timezones. } \\
\text { Differentroles are } \\
\text { supported for .LRN } \\
\text { Classes, such as students, } \\
\text { professors and } \\
\text { administrative staff. } \\
\text { Individual users can } \\
\text { personalize their own } \\
\text { personal portal layout. } \\
\text { Reference: } \\
\text { http://www.dotlnnorg pr } \\
\text { oduct/ }\end{array}$ & $\begin{array}{l}\text { CostaRica } \\
\text { Institute of } \\
\text { Technology } \\
\text { (ITCR), Costa } \\
\text { Rica } \\
\text { Center for 21st } \\
\text { Century Skills, } \\
\text { USA } \\
\text { Los Angeles } \\
\text { Unified School } \\
\text { District, USA } \\
\text { Spanish } \\
\text { National } \\
\text { University for } \\
\text { Distance } \\
\text { Education } \\
\text { (UNED), } \\
\text { Spain } \\
\text { DigitalOne, } \\
\text { Hong Kong } \\
\text { Bir } \quad \text { Zeit } \\
\text { University, } \\
\text { Palestine } \\
\end{array}$ & $\begin{array}{l}\text { It is Enterprise-class open source } \\
\text { software for supporting e-learning } \\
\text { and digital communities. }\end{array}$ & $\begin{array}{l}\text { http://www.dotir } \\
\text { n.org }\end{array}$ \\
\hline & & & & & lrn.org users & & \\
\hline 5 & & Author & $\begin{array}{l}\text { Blackboard } \\
\text { Echo } 360 \\
\text { Desire2Learn } \\
\text { StudyWiz } \\
\text { Frog }\end{array}$ & $\begin{array}{l}\text { Comply completely with } \\
\text { the accessibility } \\
\text { specifications of } \\
\text { W3CWCAG 1.0. }\end{array}$ & 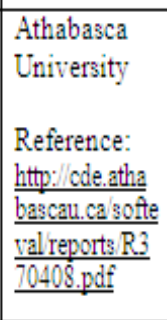 & $\begin{array}{l}\text { This provides a platform for } \\
\text { continuing professional development } \\
\text { for academic research and tutors. } \\
\text { This software can be used by visually } \\
\text { impaired and disabled learners with } \\
\text { the help of screen reader. } \\
\text { It can adapt to different technologies } \\
\text { including mobile phones, tablets, } \\
\text { PDA and text based web browsers. }\end{array}$ & www.atutor.ca \\
\hline 6. & & $\begin{array}{l}\text { Course } \\
\text { builder }\end{array}$ & & $\begin{array}{l}\text { Uses Google } \\
\text { Technologies }\end{array}$ & \begin{tabular}{|l|} 
Khan \\
Academy \\
Stanford \\
University, \\
Swiss federal \\
Institute
\end{tabular} & $\begin{array}{l}\text { It includes lessons, student activities } \\
\text { and assessments. It is basically a } \\
\text { community which is a bundle of } \\
\text { Google products. }\end{array}$ & $\begin{array}{l}\frac{\text { https: / code.googl }}{\text { e.comp/course- }} \\
\frac{\text { builder/ }}{\text { https://code.goo }} \\
\text { gle.com/p/cours } \\
\text { e-builder/ }\end{array}$ \\
\hline 7. & $\begin{array}{l}\text { Podcast } \\
\text { ing Lec } \\
\text { ture } \\
\text { recordi } \\
\text { ng }\end{array}$ & $\begin{array}{l}\text { Opencast } \\
\text { Matterhom }\end{array}$ & $\begin{array}{l}\text { MediaSite } \\
\text { Panopto }\end{array}$ & & & $\begin{array}{l}\text { Audio and video contents are } \\
\text { managed. Lecture recording can be } \\
\text { produced existing video lectures can } \\
\text { be managed and can serve designated } \\
\text { distribution channels. }\end{array}$ & $\begin{array}{l}\text { http://opencast.o } \\
\mathrm{rg} \text { matterhom }\end{array}$ \\
\hline 8. & & $\begin{array}{l}\text { BigBlue } \\
\text { Button }\end{array}$ & $\begin{array}{l}\text { Sony } \\
\text { SoundForge }\end{array}$ & & & $\begin{array}{l}\text { Virtual Class Room Systems } \\
\text { BigBlue Button is an open source } \\
\text { web conferencing system built on } \\
\text { over fourteen open source } \\
\text { components to create an integrated } \\
\text { solution that runs on Mac, Unix, and } \\
\text { PC computers. }\end{array}$ & $\begin{array}{l}\text { http://www.bigb } \\
\text { luebutton.org/ }\end{array}$ \\
\hline 9. & & $\begin{array}{l}\text { Miro } \\
\text { Miro Video } \\
\text { Converter }\end{array}$ & $\begin{array}{l}\text { ANUSOAt } \\
\text { Convertor }\end{array}$ & & & $\begin{array}{l}\text { Used to convert various Media } \\
\text { Formats }\end{array}$ & $\begin{array}{l}\text { http:/ www.get } \\
\text { micro.com } \\
\text { http:/ www.miro }\end{array}$ \\
\hline
\end{tabular}




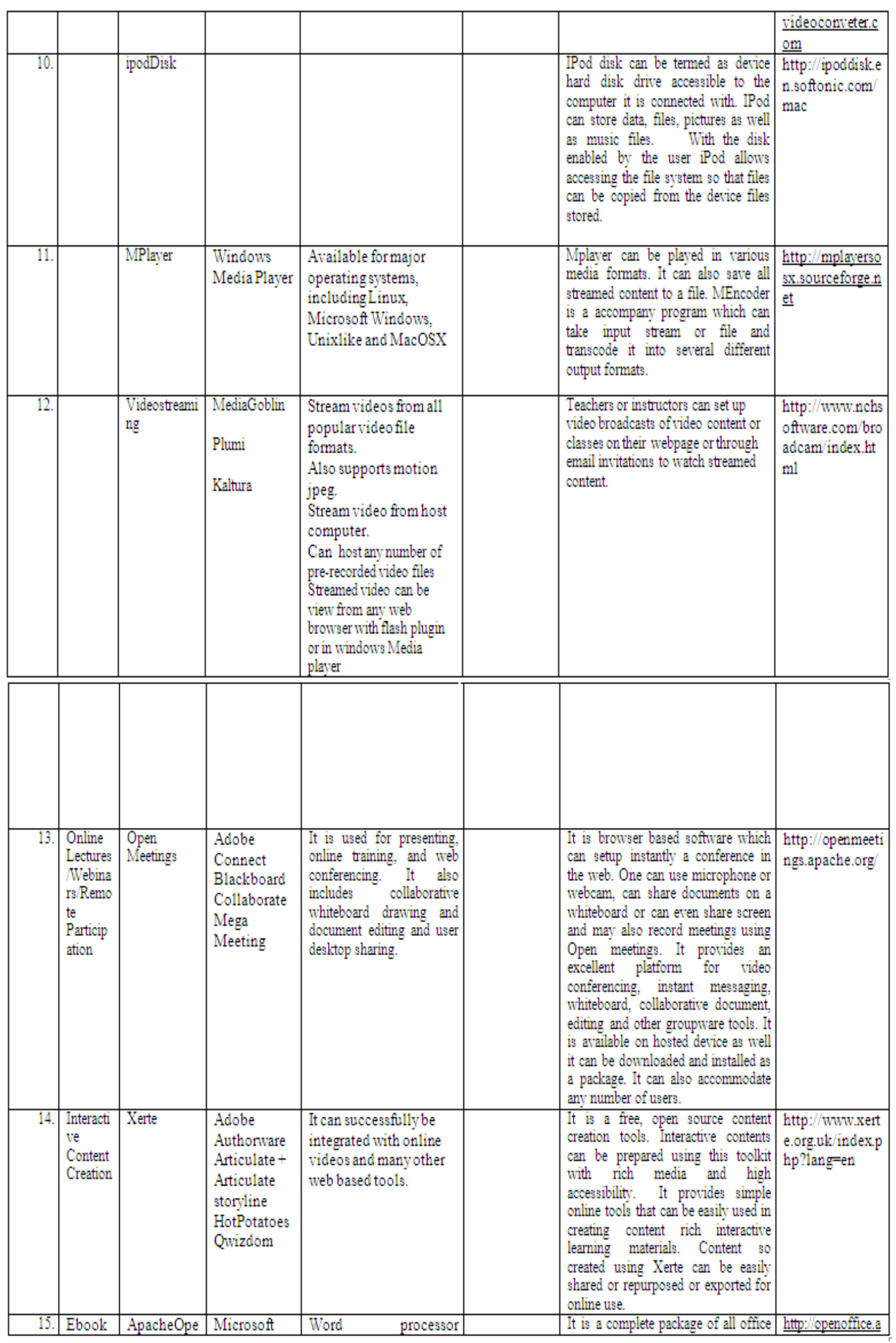


'A Study on Growth and Development of Open Source Software in Education'

\begin{tabular}{|c|c|c|c|c|c|c|}
\hline & $\begin{array}{l}\text { Authori } \\
\text { ng }\end{array}$ & \begin{tabular}{|l|} 
nOffice \\
LibreOffice \\
NeoOffice \\
\end{tabular} & $\begin{array}{l}\text { Office } \\
\text { Adobe } \\
\text { Acrobat }\end{array}$ & $\begin{array}{l}\text { Spreadsheet (Calc) } \\
\text { Presentation Application } \\
\text { Data Management } \\
\text { Application (Base) }\end{array}$ & $\begin{array}{l}\text { tools as in Microsoft Office. Its } \\
\text { default file format is ODF ie Open } \\
\text { Document Format which is an } \\
\text { ISOIEC standard. }\end{array}$ & $\begin{array}{l}\text { pache.org } \\
\text { https:/en.wikiped } \\
\text { ia.org wiki Open } \\
\text { Office }\end{array}$ \\
\hline 16. & & Sigil & $\begin{array}{l}\text { iBooks } \\
\text { Author } \\
\text { Adobe } \\
\text { InDesign }\end{array}$ & $\begin{array}{l}\text { Can be used for files in } \\
\text { TXT,HTML and EPUB } \\
\text { format }\end{array}$ & $\begin{array}{l}\text { It is free, open source-book editor for } \\
\text { files in. EPUB format. It is handy to } \\
\text { use in importing files and edit } \mathrm{e} \text { - } \\
\text { books. Creation and editing of } \mathrm{e} \text { - } \\
\text { book can be successfully possible } \\
\text { using tis software. }\end{array}$ & $\begin{array}{l}\text { http://sigilen.sof } \\
\text { tonic.com }\end{array}$ \\
\hline 17. & & $\begin{array}{l}\text { eBook } \\
\text { Speaker }\end{array}$ & & $\begin{array}{l}\text { Can orate webpage, text, } \\
\text { word, itf, email, excel, } \\
\text { pdfor clipboard data. }\end{array}$ & $\begin{array}{l}\text { Word to speech software which } \\
\text { can read the text documents } \\
\text { loudly and can convert wav file } \\
\text { so that it be listened at anytime } \\
\text { and anywhere. }\end{array}$ & $\begin{array}{l}\text { http:/web.inter.nl } \\
\text { net users lemmen } \\
\text { sjomepage uke } \\
\text { Book- } \\
\text { 3peaker.html } \\
\text { http:/www.prlog. } \\
\text { org/10371107- } \\
\text { ebook-to-speech- } \\
\text { text-speaker- } \\
\text { sottware- } \\
\text { converts-word-to- } \\
\text { voice.html }\end{array}$ \\
\hline 18. & & $\begin{array}{l}\text { Etherpad } \\
\text { Gobby }\end{array}$ & Google Docs & $\begin{array}{l}\text { Supports imports exports } \\
\text { to many major data } \\
\text { exchange formats. }\end{array}$ & $\begin{array}{l}\text { These are used for creating } \\
\text { collaborative documents. } \\
\text { Online Editors which helps in } \\
\text { collaborative editing. }\end{array}$ & \\
\hline 19. & \begin{tabular}{l|} 
E- \\
portfoli \\
0
\end{tabular} & Mahara & & $\begin{array}{l}\text { Mahara imports and } \\
\text { exports data and allow user } \\
\text { to take content from one } \\
\text { installation to other. }\end{array}$ & $\begin{array}{l}\text { Mahara is customisable and flexible. } \\
\text { It is the learning environment which } \\
\text { is blend of social networking tools. } \\
\text { In which one can share his/ her } \\
\text { views, ideas and knowledge. Digital }\end{array}$ & $\begin{array}{l}\text { https://mahara.o } \\
\mathrm{rg} /\end{array}$ \\
\hline & & & & $\begin{array}{l}\text { Contains tools like: } \\
\text { Users blogs } \\
\text { File manager } \\
\text { View creator }\end{array}$ & $\begin{array}{l}\text { portfolio can easily be created using } \\
\text { this sottware. }\end{array}$ & \\
\hline 20. & \begin{tabular}{|l|} 
Discuss \\
ion \\
Forums
\end{tabular} & \begin{tabular}{|l} 
Vanilla \\
Phpforums
\end{tabular} & $\begin{array}{l}\text { PHPBB } \\
\text { Forum } \\
\text { Engine }\end{array}$ & $\begin{array}{l}\text { It is termed as } \\
\text { lightweight internet } \\
\text { package which is written } \\
\text { in the PHP scripting } \\
\text { language. } \\
\text { Full Featured discussion } \\
\text { forums. } \\
\text { Forum hosting is free. } \\
\text { Variety of the themes } \\
\text { can be applied. } \\
\text { Categories can be } \\
\text { formed for forum as per } \\
\text { the registration type for } \\
\text { users. }\end{array}$ & $\begin{array}{l}\text { Vanilla Forums are open-source, } \\
\text { standards-compliant, customizable } \\
\text { discussion forums. It is pluggable, } \\
\text { themable, multilingual community - } \\
\text { building product to host a forum on } \\
\text { the server's infrastructure. It fosters } \\
\text { customised community participation } \\
\text { which automatically creates contents } \\
\text { and it drives members to pool their } \\
\text { ideas. }\end{array}$ & $\begin{array}{l}\text { http://vanillaforn } \\
\text { ms.org/ }\end{array}$ \\
\hline 21. & $\begin{array}{l}\text { Graphic } \\
s\end{array}$ & OpenGL & $\begin{array}{l}\text { DX Studio } \\
\text { Electric Image } \\
\text { Animation } \\
\text { System }\end{array}$ & $\begin{array}{l}\text { It language and platform } \\
\text { independent }\end{array}$ & $\begin{array}{l}\text { Open Graphics Library is a cross } \\
\text { language multiplatform API for } \\
\text { developing } 2 \mathrm{D} \text { and } 3 \mathrm{D} \text { computer } \\
\text { graphics. It is generally used in } \\
\mathrm{CAD} \text {, virtual reality, scientific } \\
\text { visualisation, flight simulations } \\
\text { and video games. }\end{array}$ & $\begin{array}{l}\text { http://www.open } \\
\text { gl.org/ }\end{array}$ \\
\hline 22. & \begin{tabular}{|l|} 
Interact \\
ive \\
Whiteb \\
oard
\end{tabular} & OpenSankore & SmartBoard & $\begin{array}{l}\text { Range of tools can be } \\
\text { adapted as per user's } \\
\text { requirements. }\end{array}$ & $\begin{array}{l}\text { It is also translated into many } \\
\text { different languages. Course contents } \\
\text { can be supplemented with flash } \\
\text { animations, images, audio, videos or } \\
\text { by including existing pdf or ppt }\end{array}$ & $\begin{array}{l}\text { http:/ wwww.opens } \\
\text { tudent.ca }\end{array}$ \\
\hline
\end{tabular}


'A Study on Growth and Development of Open Source Software in Education'

\begin{tabular}{|c|c|c|c|c|c|c|c|}
\hline & \begin{tabular}{|l|} 
Softwar \\
e
\end{tabular} & & & & & documents. & \\
\hline 23. & \begin{tabular}{|l|} 
Classio \\
om \\
Manage \\
ment
\end{tabular} & $\begin{array}{l}\text { ITALC } \\
\text { (Intelligently } \\
\text { Teaching and } \\
\text { Learning } \\
\text { with } \\
\text { Computer) } \\
\end{array}$ & MasterEye & $\begin{array}{l}\text { It is powerful didactical } \\
\text { tools for teachers. It can } \\
\text { control other computers on } \\
\text { the same network. }\end{array}$ & & $\begin{array}{l}\text { Monitoring of computer lab is } \\
\text { possible. } \\
\text { Students from home can also join } \\
\text { lessons via VPN connections. }\end{array}$ & $\begin{array}{l}\text { http: italc.sourcef } \\
\text { orge.net } \\
\text { http:/en.wikipedi } \\
\text { a.org wikiITALC }\end{array}$ \\
\hline 24. & \begin{tabular}{l|} 
M- \\
Educati \\
on
\end{tabular} & Molly & \begin{tabular}{|l|} 
Microsoft \\
OfficeMobile
\end{tabular} & $\begin{array}{l}\text { Molly is a web-based } \\
\text { application framework } \\
\text { targeting all phones, 'smart' } \\
\text { or otherwise. Native } \\
\text { applications can only target } \\
\text { a few classes of device, } \\
\text { leaving a large number of } \\
\text { potential users unable to } \\
\text { use the service. }\end{array}$ & & $\begin{array}{l}\text { Molly is a framework for the } \\
\text { rapid development of information } \\
\text { and service portals targeted at } \\
\text { mobile internet devices. The } \\
\text { framework follows a philosophy, } \\
\text { featuring a wide variety of } \\
\text { applications and connectors to } \\
\text { common and standards-based } \\
\text { systems including the Sakai } \\
\text { Virtual Learning Environment. }\end{array}$ & $\begin{array}{l}\text { http://mollyproje } \\
\text { ct.org }\end{array}$ \\
\hline 25. & \begin{tabular}{|l|} 
Manage \\
ment \\
Informat \\
ion \\
System \\
(NIS) S \\
tudent \\
Records
\end{tabular} & $\begin{array}{l}\text { A1 } \\
\text { Academia }\end{array}$ & $\begin{array}{l}\text { SIMS (School } \\
\text { Information } \\
\text { Management } \\
\text { System) }\end{array}$ & $\begin{array}{l}\text { It contains the following } \\
\text { features and modules: } \\
\text { Admissions module } \\
\text { RegistrationModule } \\
\text { Class Scheduling } \\
\text { Curriculum Management } \\
\text { Workload Management } \\
\text { Facilities Management } \\
\text { Class Attendance } \\
\text { Accommodation } \\
\text { Management } \\
\text { Financial Aid }\end{array}$ & & $\begin{array}{l}\text { It is an Enterprise Academic } \\
\text { Management Solution. It is a } \\
\text { complete bundle of administrative } \\
\text { and university's management } \\
\text { functions especially designed for } \\
\text { higher learning institutions. It } \\
\text { contains entire set of information } \\
\text { regarding processes, records, } \\
\text { curriculum and administrative } \\
\text { tasks. } \\
\text { Reference:htps:/ en.wikipedia.org } \\
\text { wikiAl ERP }\end{array}$ & $\begin{array}{l}\text { http://academia. } \\
\text { a1.io/ }\end{array}$ \\
\hline 26. & & Fedena & & \begin{tabular}{|l|} 
Requires ruby \\
The following are main
\end{tabular} & \begin{tabular}{|l|} 
Education \\
Department of
\end{tabular} & Can automate the tasks of managing & $\begin{array}{l}\text { http: projectfeden } \\
\text { a.org } \\
\text {. }\end{array}$ \\
\hline & & & & $\begin{array}{l}\text { modules of this source } \\
\text { tool: } \\
\text { Admissions examinations } \\
\text { Attendance } \\
\text { Hostel library } \\
\text { Transport }\end{array}$ & $\begin{array}{l}\text { Government of } \\
\text { Kerala }\end{array}$ & a school. & $\begin{array}{l}\text { Pandey Vinayak, } \\
\text { Use Fedenato } \\
\text { Manage Your } \\
\text { School, PageNo. } \\
42.43 \\
\text { Linux, Vol 10, } \\
\text { November, } 2012 \\
\text { Issue } \\
\end{array}$ \\
\hline 27. & & $\begin{array}{l}\text { School Tool } \\
\text { Open student }\end{array}$ & & $\begin{array}{l}\text { Student contact } \\
\text { management } \\
\text { Calendars for the school } \\
\text { Resource Allocation } \\
\text { Teacher grade books } \\
\text { Class attendance } \\
\text { Report card Generation }\end{array}$ & & $\begin{array}{l}\text { Complies student information } \\
\text { system, their grade book, attendance, } \\
\text { calendaring and reporting } \\
\text { This tool is mainly used for primary } \\
\text { and secondary schools. } \\
\text { Applications can be customised as } \\
\text { per the requirement of schools. }\end{array}$ & $\begin{array}{l}\text { http://www.scho } \\
\text { oltool.org }\end{array}$ \\
\hline 28. & $\begin{array}{l}\text { Science } \\
\text { Educati } \\
\text { on }\end{array}$ & Scilab & $\begin{array}{l}\text { MATLAB } \\
\text { MAPLE }\end{array}$ & $\begin{array}{l}\text { User can write programs } \\
\text { in its own programming } \\
\text { language. } \\
\text { Can accommodate } \\
\text { hundreds of } \\
\text { mathematical functions } \\
\end{array}$ & & $\begin{array}{l}\text { Designed for scientific and } \\
\text { numerical computations. }\end{array}$ & $\begin{array}{l}\text { https:/www.scila } \\
\text { b.org }\end{array}$ \\
\hline 29. & & Maxima & $\begin{array}{l}\text { MATLAB } \\
\text { Mathematica } \\
\text { Maple } \\
\text { Mupad } \\
\text { MathCad }\end{array}$ & $\begin{array}{l}\text { Complete programming } \\
\text { language. } \\
\text { Is available on Linux as } \\
\text { well as Windows. }\end{array}$ & & $\begin{array}{l}\text { Full-featured computer Algebra } \\
\text { system. } \\
\text { Specializes in symbolic operations }\end{array}$ & $\begin{array}{l}\text { http://maxima.en } \\
\text { 3oftonic.com }\end{array}$ \\
\hline 30. & & Grace & & $\begin{array}{l}\text { Available both on } \\
\text { Windows and Linux }\end{array}$ & & $\begin{array}{l}\text { Graph plotting tool } \\
\text { Can be used for both linear and } \\
\text { nonlinear curve fitting }\end{array}$ & $\begin{array}{l}\text { http:/ wwww.graces } \\
\text { oftware.com }\end{array}$ \\
\hline
\end{tabular}




\begin{tabular}{|c|c|c|c|c|c|c|c|}
\hline 31. & & Celestia & $\begin{array}{l}\text { TheSky } \\
\text { (astronomy } \\
\text { software) }\end{array}$ & $\begin{array}{l}\text { 3D Astronomy } \\
\text { Programme } \\
\text { Available for Linux, } \\
\text { Windows, Mac }\end{array}$ & & $\begin{array}{l}\text { Programme which can depict the } \\
\text { Universe at any point of time and } \\
\text { from any place. } \\
\text { Celestia displays the orbital path } \\
\text { of any object, allows users to orbit } \\
\text { around the plants and track } \\
\text { various objects in space. }\end{array}$ & $\begin{array}{l}\text { http://www.shatt } \\
\text { ers.net/celestia }\end{array}$ \\
\hline 32. & & Avogadio & $\begin{array}{l}\text { 3D Molecules } \\
\text { Edit and Drill } \\
\text { Accelrys Draw } \\
\text { ChemDoodle } \\
\text { ACD } \\
\text { Chemsketch }\end{array}$ & $\begin{array}{l}\text { Designed for cross- } \\
\text { platform }\end{array}$ & & $\begin{array}{l}\text { Used for students and researchers } \\
\text { An advanced molecular editor and } \\
\text { visualize. } \\
\text { Designed for use in computational } \\
\text { chemistry, molecular modeling, } \\
\text { bioinformatics, material sciences } \\
\text { and related area. }\end{array}$ & $\begin{array}{l}\text { http://avogadro. } \\
\text { openmoleculesn } \\
\text { et/wiki/Main_Pa } \\
\text { ge }\end{array}$ \\
\hline 33. & & Latex & $\begin{array}{l}\text { WinEdt } \\
\text { (Shareware), } \\
\text { Scientific } \\
\text { Word }\end{array}$ & $\begin{array}{l}\text { Can be used in any } \\
\text { platforms }\end{array}$ & $\begin{array}{l}\text { American } \\
\text { Mathematical } \\
\text { Society }\end{array}$ & $\begin{array}{l}\text { Used to produce scientific } \\
\text { documents, especially where } \\
\text { mathematical symbols are used. }\end{array}$ & $\begin{array}{l}\text { http://www.latex } \\
\text {-project.org/ }\end{array}$ \\
\hline 34. & \begin{tabular}{|l|} 
Statistic \\
3
\end{tabular} & R-Project & IBM SPSS & $\begin{array}{l}\text { A well-developed, simple } \\
\text { and effective programming } \\
\text { language which includes } \\
\text { conditionals, loops, user- } \\
\text { defined recursive functions } \\
\text { and input and output } \\
\text { facilities. }\end{array}$ & & $\begin{array}{l}\text { Is used for Data Analysis \& } \\
\text { Presentation } \\
\text { It is used in statistical computing } \\
\text { and graphics. }\end{array}$ & $\begin{array}{l}\frac{\text { htpp:/ww1w.r- }}{\text { project.org }} \\
\text { http://www.r- } \\
\text { project.org/ }\end{array}$ \\
\hline 35. & \begin{tabular}{|l|} 
Account \\
ing and \\
Finance
\end{tabular} & $\begin{array}{l}\text { Eqonomize } \\
\text { Slrooge } \\
\text { Grisbi }\end{array}$ & \begin{tabular}{l|} 
SAP \\
BusinessOne \\
Sage \\
Tally \\
Traverse \\
Microsoft \\
Money \\
\end{tabular} & & & $\begin{array}{l}\text { Software with which one can create } \\
\text { accounts, record incomes and } \\
\text { expenses and can schedule } \\
\text { transactions for a financial year. }\end{array}$ & $\begin{array}{l}\text { http://egonomize. } \\
\text { sourceforge.org } \\
\text { http://wwww.grisbi. } \\
\text {.org } \\
\text { http://skrooge.org } \\
\text { Reference: } \\
\text { http://en.wikipe }\end{array}$ \\
\hline & & & & & & & $\begin{array}{l}\text { dia.org wiki } \mathrm{Co} \\
\text { mparison_of ac } \\
\text { counting_softwa } \\
\text { re. }\end{array}$ \\
\hline
\end{tabular}

Author would like to express sincere thanks to the Coordinators of PGDEL programme and STRIDE ,IGNOU for giving a detailed insight about e-learning. 